\title{
Digital Content Model Framework Based on Social Studies Education
}

\author{
Feri Sulianta ${ }^{1}$, Sapriya $^{1}$, Nana Supriatna ${ }^{1} \&$ Disman $^{1}$ \\ ${ }^{1}$ School of Postgraduate Studies, Universitas Pendidikan Indonesia, Bandung, Indonesia \\ Correspondence: Feri Sulianta, School of Postgraduate Studies (Study Program of Social Studies Education), \\ Universities Pendidikan Indonesia, Bandung, Indonesia. E-mail: ferisulianta@upi.edu
}

Received: August 9, 2019

doi:10.5430/ijhe.v8n5p214
Accepted: August 31, 2019

Online Published: September 2, 2019

URL: https://doi.org/10.5430/ijhe.v8n5p214

\begin{abstract}
The growth of the digital world brings positive and also negative influences in the society, For example, the overwhelmed of uneducated material, provoking news, the contents teaches unhealthy behavior, or hoaxes. Most of the people do not have abilities to recognize quality contents or well written contents. Those conditions are really matter, in the 21st century, people must have digital literacy the competencies. In order that the societies will be ready to deal with technology and to address the usefulness of digital content.

The community must act as a smart content consumer, and also as a good content producer, so that people have ability to create good digital content and get the benefit of information. However, due to the lack of digital content framework, people have difficulty assessing the quality of digital content, and it is difficult to create content with good criteria. Therefore, it is important to create digital content standards that have a positive goal in the age of technology.

To make digital content standards a digital content model was developed which was developed with Research and Development methods, involved students and cyber society on the internet. The digital content framework contains several elements, such as: pillar of social studies education, writing, knowledge, digital media, search engine optimization, and digital copyrights, which will be published in User Generated Content Platform. Furthermore, digital content model framework has been tested and has a useful principle that is used as a guidance for making high quality digital content which considers the virtue of society and the art of state of information technology.
\end{abstract}

Keywords: digital society, media literacy, social sciences education, digital content model, user generated content platforms, research and development methods

\section{Introduction}

\subsection{Previous Digital Content Model}

Rapid technological developments affect the way a person makes, presents, and gets information. Most people make and launch digital information just digitizing, without considering other important factors. As a result, content with low visibility, content that is not well written, and content that does not have a positive contribution to society or content that is difficult to access because it does not meet the standards of information technology feasibility, is alleged as a problem with the abundance of non-quality content.

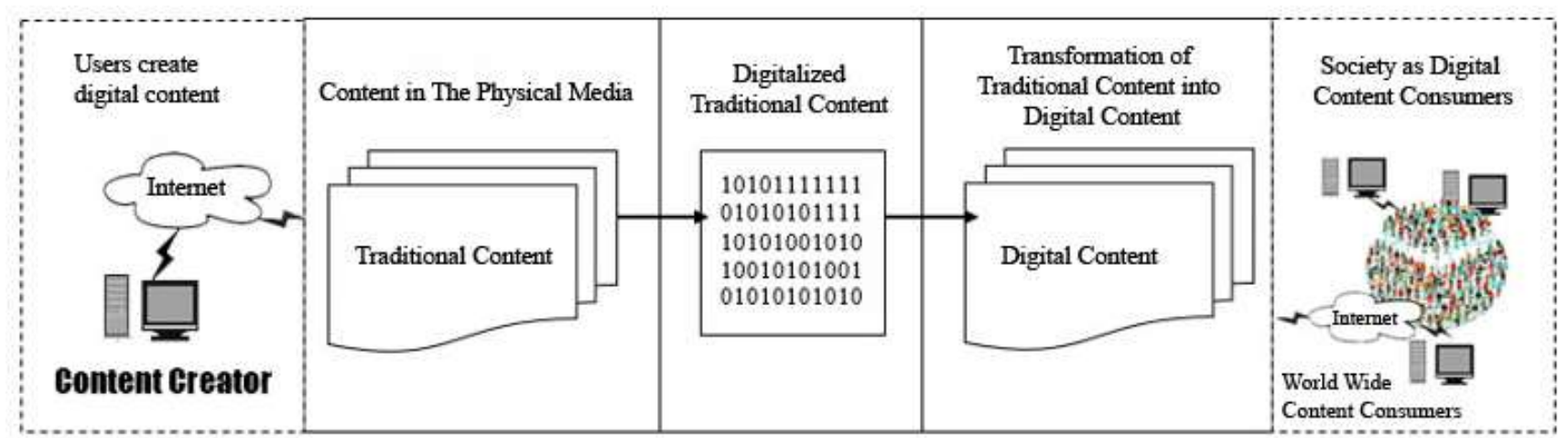

Figure 1. Digital Content Creation 
The picture above shows that anyone can access the internet to create digital content, use traditional content as a reference and package it using digital media, and release it on the internet, without understanding the quality of the content used.

\subsection{Disadvantage of Old Digital Content Model}

Most digital content that exists today, does not heed intellectual property rights, does not include sources and protection of intellectual property rights. Other things, improper writing, lack of understanding of digital technology, and lack of media literacy, are causing the low quality of today's digital content. Content that is often found on the internet does not all have good visibility, content is not easily identified by search engines such as Google. This is because the digital content is only digitalization of traditional content, without applying the correct writing system for search engines to recognize. Google Explorer Robot will map information on various websites in the virtual universe. But low quality content cannot be recognized by the Google search engine.

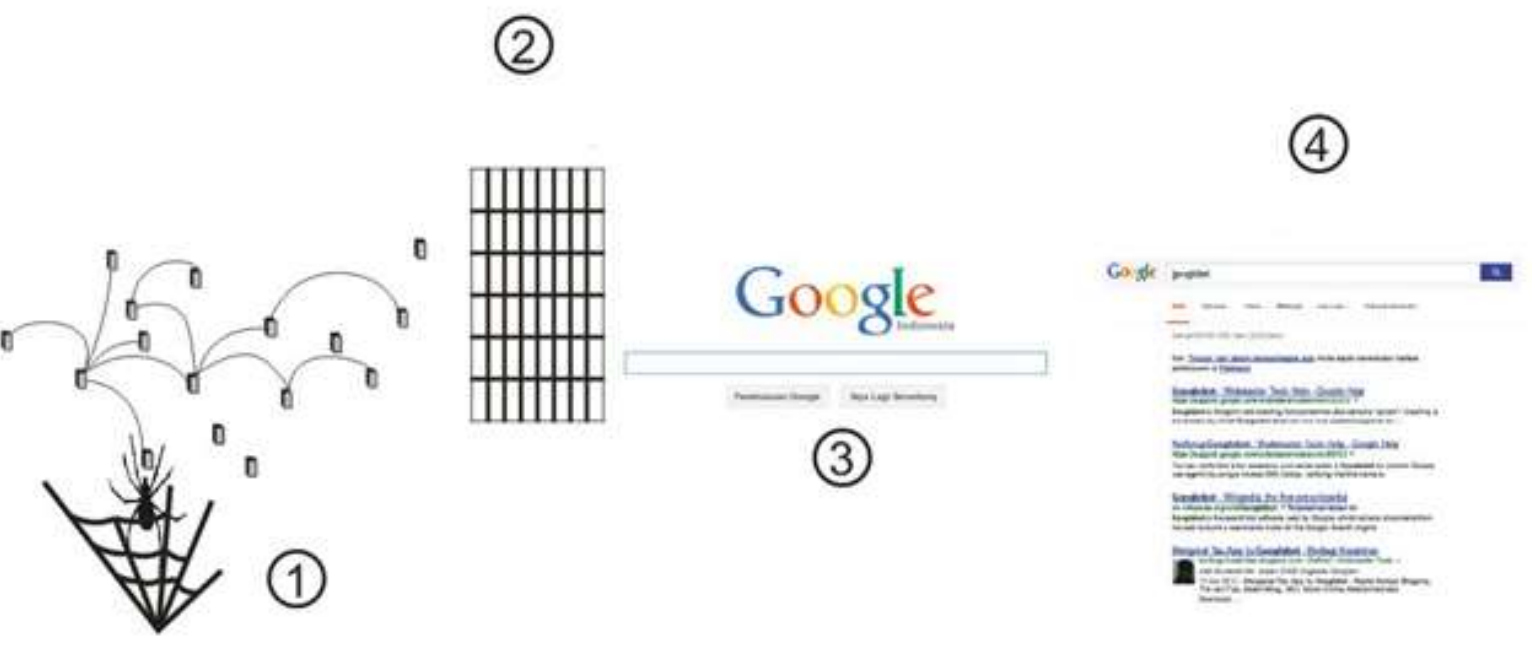

Figure 2. Google Spider Mechanism to Identify Digital Content (1) Crawling (2) Indexing (3)Querying (4)Retrieving Google had a number of mechanisms in its algorithms for indexing purposes whose purpose is to improve search accuracy. Google uses a robot known as Googlebot (web spider) which is tasked with exploring every web page without stopping. When entering keywords in the search box, the Google Algorithm will search for the most relevant content on the Googlebot browsing index several considerations: web page titles, links, content renewal, page rank, words on web content, word equivalence with keywords, mode spelling, quality of content.

\subsection{The Virtue of Educative Digital Content Model}

Basically the purpose of Social Studies Education (SSE), namely to foster students into citizens and community members who know their rights and obligations, who also have responsibility for the broadest common welfare. Because students who are nurtured through SSE not, only have high knowledge and thinking skills, but students are expected to have a high awareness and responsibility for themselves and their environment. SSE is aimed at educating good citizenship, namely fostering students to become citizens and citizens who know their rights and obligations, who also have responsibility for the broadest common welfare. Because students who are trained through social studies do not, only have high-level knowledge and thinking skills, but students are also expected to have high awareness and responsibility for themselves and their environment. Social studies learning is not intended to foster mental awareness of responsibility for his own rights, and obligations to society, nation, and state. Integrating SSE into the Model Digital content is an attempt to apply the theories, concepts, and principles of social science to examine experiences, events, symptoms, and social problems that actually occur in society so that it is able to train the skills of students both their physical skills, and thinking abilities in critically assessing information, it becomes digital literate.

The students as the part of the community must be able to involve themselves in people's lives both as citizens who are aware of responsibility by displaying behavior, actions, and actions that are full of meaning for the common good. In the end, they are expected to become competent citizens as a result of social studies. 


\subsection{Hypotheses}

Based on description of the identification of the above problems, there are no standards that can be used in making a good digital content model as a reference in creating digital content that contributes to digital literacy, a digital content model is needed to guide digital content that contributes positively to students and digital society, as well as media literacy. This model will be implemented in the User Generated Content Platform (UGC), internet service to empower online content media intended by system users. Based on formulation of the problems mentioned above, it can be explained in general that the general objective in this study is to create, describe and analyze digital content models that will use as a guide in creating digital content that contributes positively to students, and the digital community, as well as media literacy The objectives of this study is modeling, describing and analyzing digital content models in general today that are used as media in producing content as media literacy published on the User Generated Content Platform. Furthermore, this research will describe and analyze the digital content models that can educate students and communities within the scope of the study of Social Sciences Education.

\section{Method}

\subsection{Research and Development Method}

To create a digital content model, the Research and Development ( $R$ \& D) educational research method was used using the version proposed by Sugiyono (2013: 407). In this research, Research and Development is used to produce digital content models charged with Social Sciences aimed to educate students in the 21 st century also to educate the digital community of digital literacy. Research that uses a research and development approach model approach is intended to develop and validate educational products. This method divides the work step into ten stages, as shown in the following picture:

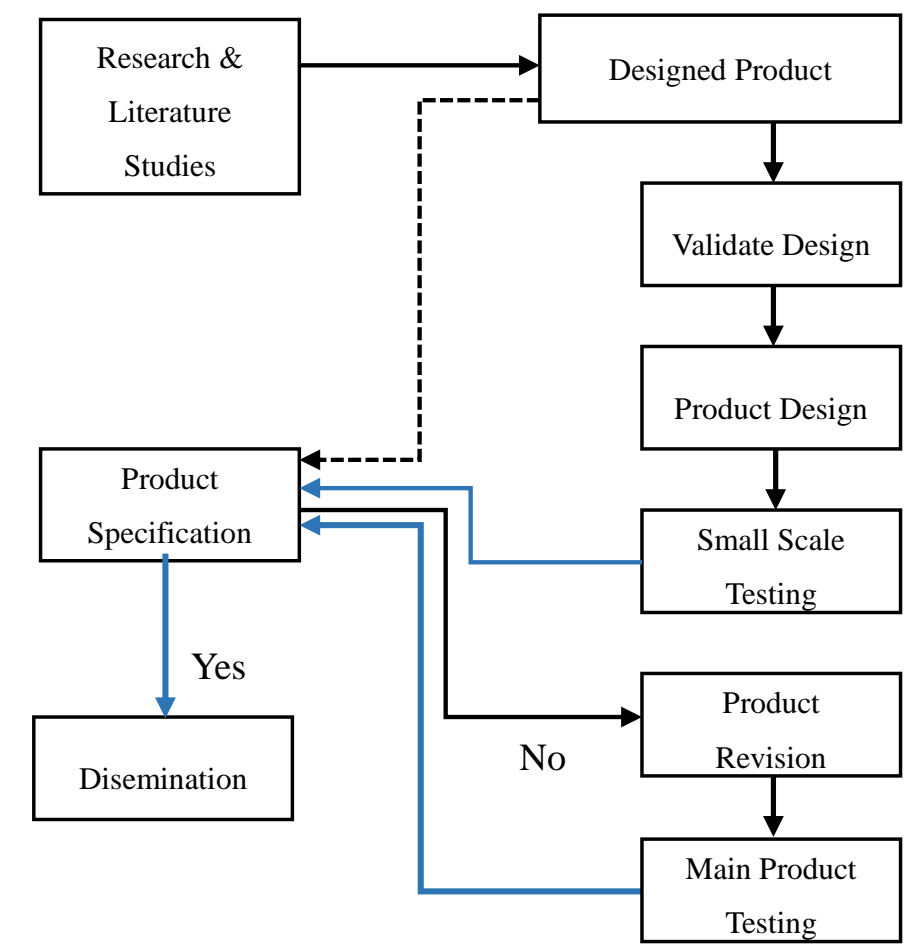

Figure 3. Step by step Research and Development Method (R \& D) (Sugiyono, 2013)

An important instrument in research uses the R \& D method, which is to develop research instruments used at each stage of research. Many methods can be used in R \& D research, such as: surveys, case studies, previous research studies and formative evaluations, repeated field testing (Borg \& Gall, 1983). Some instruments used in this study includes: questions, interviews, and documentation.

\subsection{Research Subjects, Stages and Population}

Research on digital content models based on Social Sciences at the User generated Content Platform as a media literacy to educate students and the digital community, used Research and Development methods. Research involved audience subjects, categorized into three stages, namely observation, extensive research and research limited scale as follows: 


\subsubsection{Observation Stage}

At this stage it is the initial stage of the Research and Development method that involves respondents with diverse backgrounds namely educators, students in the school environment as well as students at higher levels as well as digital communities or netizens, and 129 respondents collected. With a population of respondents, five educators, 33 students in the school environment, 50 students at a higher level and 42 netizens.

\subsubsection{Validation Stage}

Validation stage, it is the stage to validate the design, which is implemented using Focus Group Discussion, and the results of the Questionnaire are included in relation to the model. Various findings were used to refine the model being developed to then be brought into the FGD. This exploration is carried out in connection with the inductive pattern used in this method, which is from a specific matter to a general matter. The model design will be refined through focus group discussions (FGD) involving related experts to validate the design of digital content models. The FGD involved several experts including information technology lecturers, social science education lecturers, and Social Sciences teachers, information technology teachers. The participants are expected to improve the revised learning design.

\subsubsection{Small Scale Testing}

The population scope for small scale testing used particular class which is initially limited to one particular institution with two classes, university students with a population of 40 people. This subject is involved in research in the research phase limited scale with Research and Development methods.

\subsubsection{Main Scale Testing}

Main Scale Testing involved161 respondents with a population of educators: Eight people, students: 28 people, university students: 89 people and public, or netizens as many as 36 people. The characteristics of the population are University students, junior high school students and netizens who contribute via the internet.

\subsection{Digital Content Model}

There are key components In the digital content model, such as: SEO Techniques, Writing Systems, Social Studies Education Concept, Digital Media, Digital Copyright and Knowledge. Assessment of the feasibility of the model is translated into a questionnaire using several types of scale, including: Likert Scale, Guttman Scale, and Rating Scale for six components that are part of the digital content model. Furthermore, the results of data acquisition will be analyzed using a statistical program.

This digital content will be distributed to User Generated Content Platforms, the creation must also follow the rules of 'fit and proper Search Engine Optimization (SEO) parameters'. The dependence of digital content depends on and is strongly influenced by the six main components of building digital content, namely: SEO, Writing Engineering, Content based on Social Studies Education, Digital Media, Digital Copyright, and knowledge.

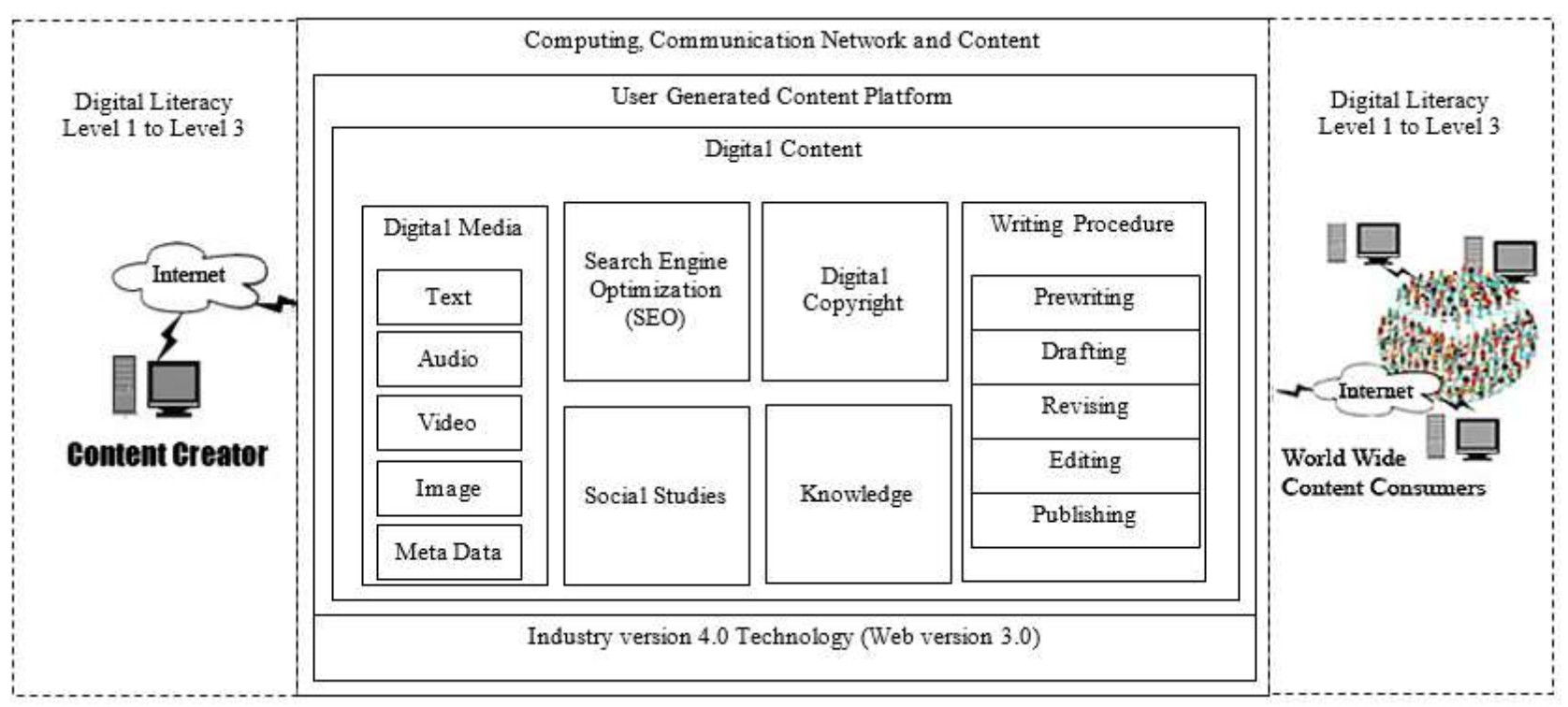

Figure 4. Digital Content Model Framework Based on Social Studies Education 
The content creation step begins by determining the three main components as the basis for the writing idea which can be explained in a block diagram as follows:

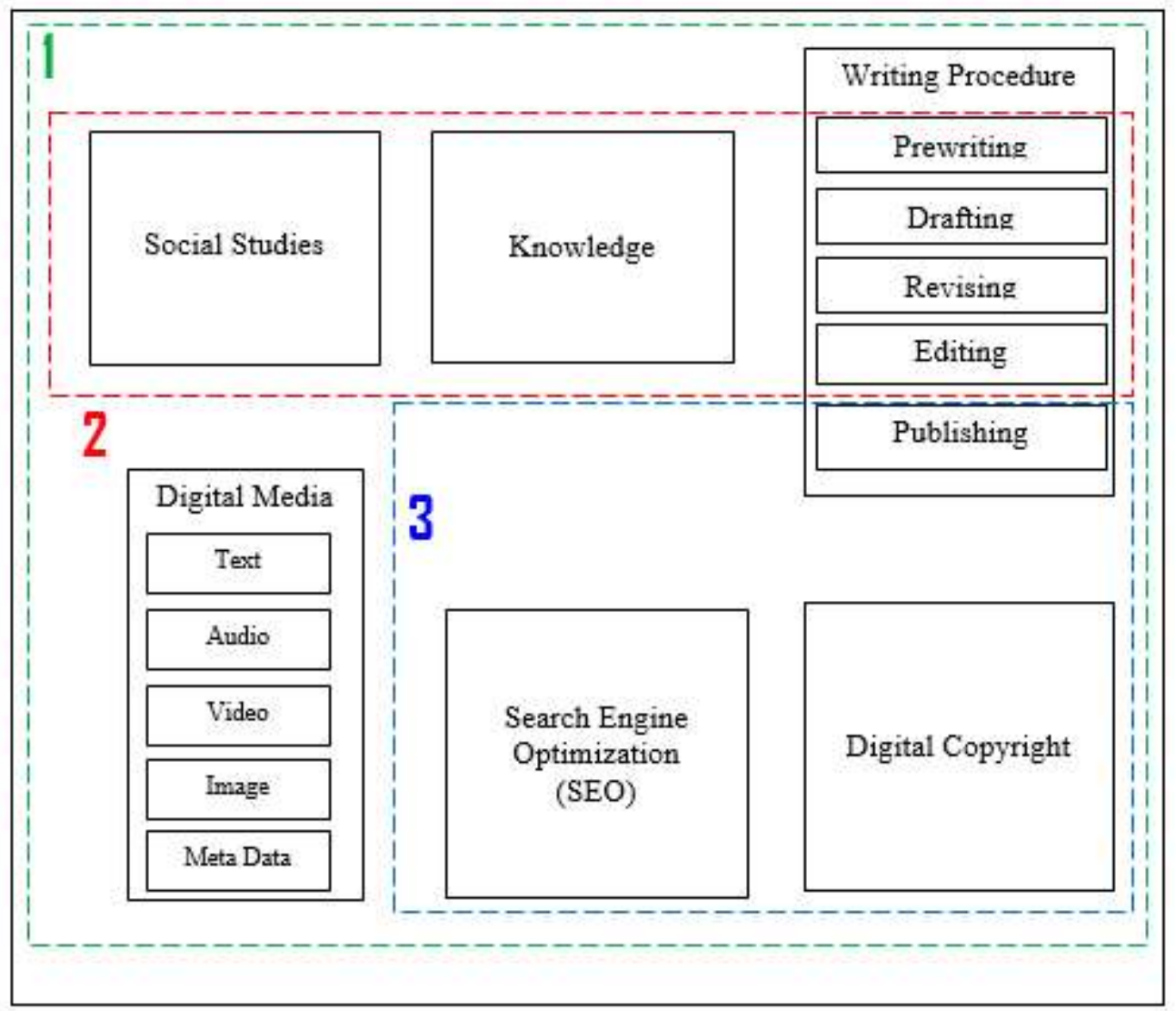

Figure 5. Three main components in Digital Content Model

\section{Results}

The results of the digital content model will be used as guidelines in making digital content, and support digital literacy. Digital content in general does not have digital content standards and guidelines, lack of benefit principles and lack of understanding of technology. Therefore, in this study, a digital content model was created which is a product of social science education published on the User Generated Content Platform.

This model received a positive response from the beginning of the introduction of the model, where in the limited stage of research the respondent's attitude regarding the feasibility of the digital content model was mapped to a very positive attitude category of $60 \%$ and a positive attitude of $40 \%$. Where, there are 24 people who argue that the digital content model is feasible and highly qualified as a digital content model to create useful content. Likewise, there are 16 people who see it as a decent model. Whereas in the large scale test shows the attitude of respondents regarding the feasibility of digital content models that are mapped to the category of very positive attitudes, which is $69.57 \%$ and a positive attitude $30.43 \%$. The composition of the respondents consisted of 112 people who argued that the digital content model is feasible and highly qualified as a content model used to create useful content. Similarly, there are 49 people who see it as a decent model.

Large-scale field testing is a broader product testing, involving students in school education, students in higher education, educators, and society in general. This is intended to see how effective the design of digital content models is, as well as the presentation so that based on the results of field tests, effective designs will be obtained, both regarding substance and methodology. 


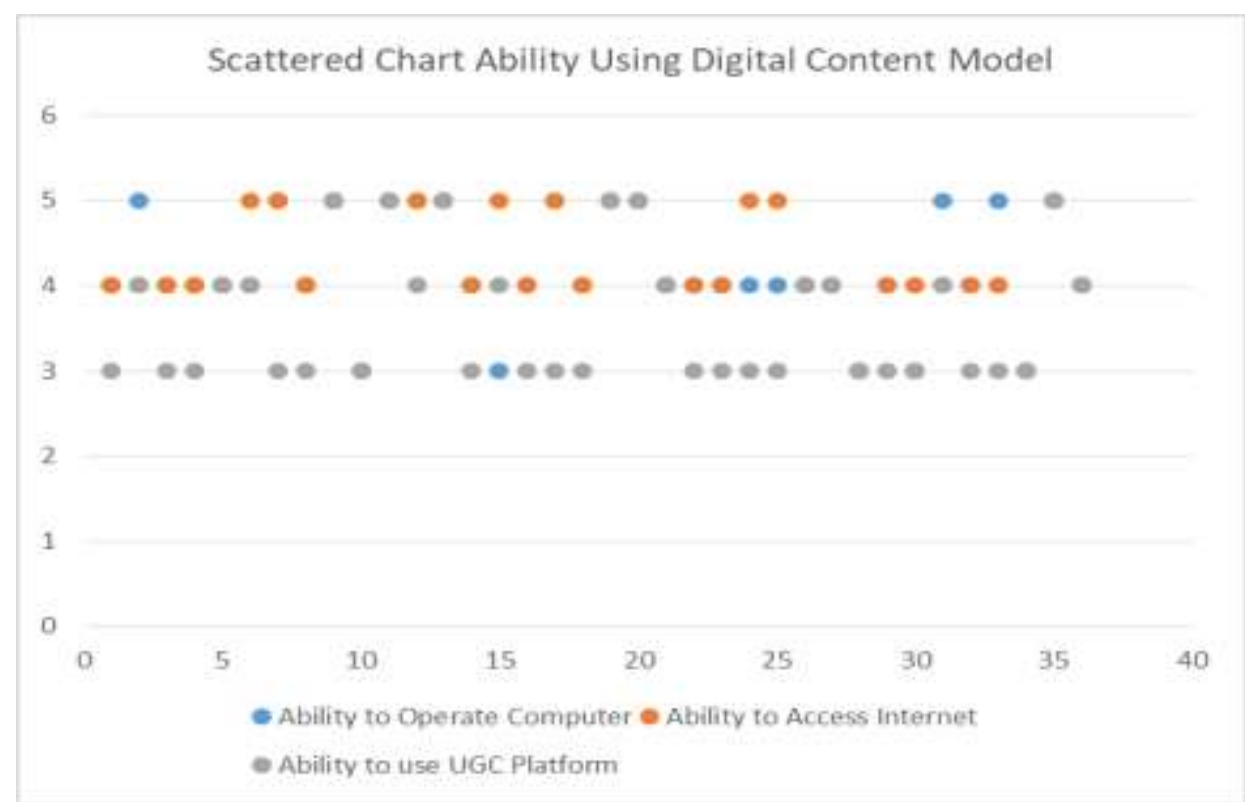

Figure 6. Scattered of audiences to use the digital content model based on three major skills

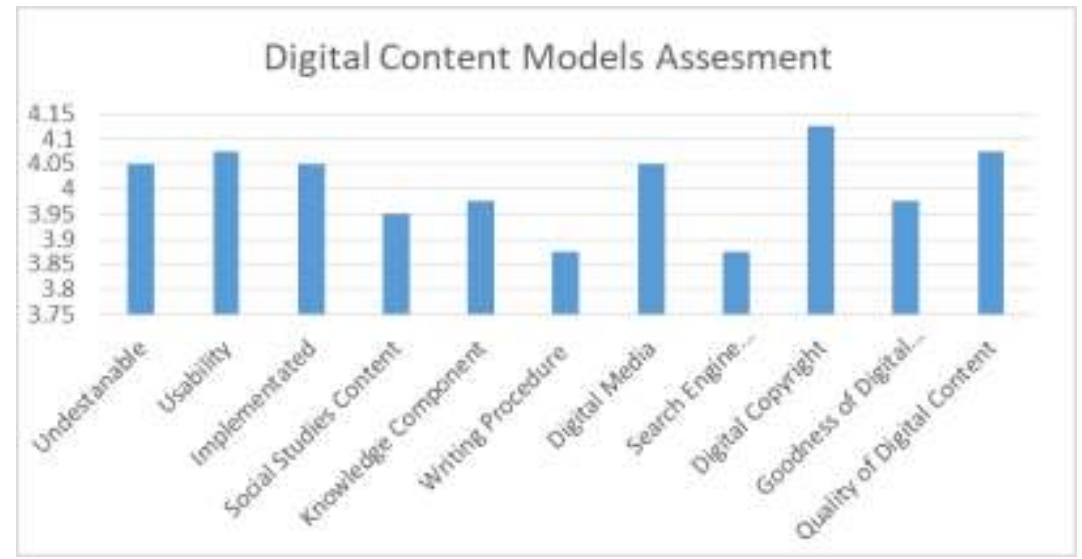

Figure 7. Digital Content Model Assessment form the Audiences Perspective

\section{Discussion}

The digital content model with the content of social science is a guideline in creating quality content that has never before existed as a reference in creating digital content that takes into account writing, SEO criteria, forms of digital media, copyright, knowledgeable content based on social science. The benefits of this content model can be used by every level of society, educators as well as students and educating the public as well as educators and students regarding digital literacy. Making the community, not just as consumers of digital content, but as critical communities and producers or creators of quality digital content. For this reason, digital content models, and digital content model modules will be published to reach more audiences and increase the availability of digital content model learning. This step is the final stage of the final stage of the research that uses the Research and Development model approach.

\section{References}

Anderson, Lorin. \& Krathwohl, David. (2013). A Taxonomy for Learning, Teaching, and Assesing: A Revision of Bloom's Taxonomy of Educatioanl Objectives. Pearson, 77-81.

Art Silverblatt Media Literacy (1995). Keys to Interpreting Media Messages. London: Praeger.

Bagja, Waluya. (2012). Pengantar Ilmu Sosial. Diakses. Universitas Pendidikan Indonesia.

Dogruera. Nazan, Eyyamb, Ramadan. \& Menevisab, Ipek. (2011). The use of the internet for educational purposes. Elsevier. Procedia - Social and Behavioral Sciences, 28, 606-611.

Fitzgerald, Brian. \& Gao, Fuping. (2008). Copyright Law, Digital Content and The Internet in The Asia-Pacific. Sydney University Press. 
Jones, Glenda. \& Westhuizen, Duan. (2013). Digital Literacy in the 21st Century: Fact or Fiction? Research Gate, 12-17.

Kumar, Lalit. \& Kumar, Naresh. (2014). SEO Techniques for a Website and its Effectiveness in Context of Google Search Engine. International Journal of Computer Sciences and Engineering, 2(4), 113-118.

Kumar, Vinit. \& Pooja, Gunjan. (2012). Search engine optimization with Google. IJCSI International Journal of Computer Science Issues, 9(1), 206-2014.

Llorente, José. (2017). The post-truth era: reality vs. perception. Spain. Uno Magazine.

Martin, Allan. (2008). Digital literacies: concepts, policies and practices. Die Deutsche Bibliothek.

Mhschool.com. (2009). Social Studies Education Theme Topics.

National Council for the Social Studies (NCSS). (2008). Curriculum Guidelines for Social Studies Teaching and Learning.

Rose, Stephen. Fernlund, Phyllis. (1997). Using Technology for Powerful Social Studies Learning. National Council forthe Social Studies, 61, 160-160.

Sapriya. Pendidikan. (2011). IPS: Konsep dan Pembelajaran. Bandung: Remaja Rosdakarya Offset.

Sartono. (2016). Pemanfaatan Blog Sebagai Media Pembelajaran Alternatif di Sekolah. Transformatika, 12(1), Maret ISSN 0854-8412. 120-134.

Saubari, Norazilah. \& Baharuddin, M. Fazli. (2016). Digital Literacy Awareness among Student. ISSN: 2180-0065 RESEARCH HUB, 2(1), tahun 2016.

Sawyer, Steve. \& Rosenbaum, Howard. (2003). Social Informatics in the Information Sciences: Current Activities and Emerging Directions. Informing Scince, 3(2).

Sawyer, Steve. \& Tyworth, Michael. (2006). Social Informatics: Principles, Theory, and Practice. Social Informatics: An Information Society for all? Proceedings of the 7th International Conference 'Human Choice and Computers', IFIP-TC9 'Relationship between Computers and Society', Springer: London. 49-6.

Shettar, Iranna. (2010). Copyright Issues in Digital Media. International Conference on Knowledge for All: Role of Libraries and Information Centres. November.

Silalahi, Albinus. (2017). Development Research (Penelitian Pengembangan) dan Research \& Development (Penelitian \& Pengembangan) dalam Bidang Pendidikan/Pembelajaran. Disampaikan pada Seminar \& Workshop Penelitian Disertasi Program Doktoral. Pasca Sarjana Universitas Negeri Medan.

Stein, Laura. \& Prewett, Anita. (2009). Media Literacy Education in the Social Studies: Teacher Perceptions and Curricular Challenges. Teacher Education Quarterly, Winter.

Steve, Wheeler. (2012). Digital literacies for engagement in emerging online cultures. eLC Research Paper Series, 5 , $14-25$.

Stock, Paul. \& Burton R. J. F. (2011). Defining Terms of Integrated (Multi-Inter-Trans-Disciplinary). Sustainability Research. Journal Sustainability, 3,1090-1113; doi:10.3390/su3081090.

Sugiyono, Metode. (2017). Penelitian Pendidikan Pendekatan Kuantitatif, Kualitatif, dan R \& D. Bandung : Alfabeta.

Sukmadinata, Nana Syaodih. (2008). Metode Penelitian Pendidikan. Bandung: Remaja Rosdakarya.

Sulianta, Feri. (2007). Cyberworld Ethics-Yang Perlu Remaja dan Orangtua Ketahui. Yogyakarta. Penerbit Andi.

Sulianta, Feri. (2016). Langkah Kilat SEO. Yogyakarta. Penerbit Andi.

Sulianta, Feri. \& Zainul, Asmawi. (2017). User Generated Content as A Platform To Develop State Of The Art Creative Learning Strategy. National Seminar on Social Studies and History Education ISSSHE 2017. Universitas Pendidikan Indonesia.

Supriatna, Nana. (2018). Prosa dari Praha. PT Remaja Rosdakarya.

Tally, Bill. (2007). Digital Technology and the End of Social Studies Education. Theory and Research in Social Education Spring, 35(2), 305-321

UKSW Salatiga. (2018). Analisis Literasi Digital: Studi Pemanfaatan Jurnal Elektronik Oleh Mahasiswa Magister Manajemen Di Perpustakaan Uksw Salatiga. 2007 [cited 2019 Juni 24]. http://digilib.uin-suka.ac.id/23912/1/1420011034_bab-i_iv-atau-v_daftar-pustaka.pdf.

Wahidmurni. (2017). Pemaparan Metode Penelitian Kuantitatif. UIN Maulana Malik Ibrahim Malang.

Wheeler, Steve. (2012). Digital literacies for engagement in emerging online cultures. eLC Research Paper Series, $5(1), 14-25$. 